\title{
Foreign Direct Investment and Growth : EU, EMU, and Transition Economies
}

\author{
Anastasia Angelopoulou \\ University of Peloponnese, Tripolis, Greece \\ Panagiotis Liargovas \\ University of Peloponnese, Tripolis, Greece
}

\begin{abstract}
This paper empirically examines the relationship between Foreign Direct Investment (FDI) and economic growth conducting a panel data analysis for a period of 20 years (1989 2008) in three different country groups: European Union member-countries, European Monetary Union member-countries, and countries in transition. These three country groups differ in many dimensions, one of which is their degree of economic integration. In contrast to the theoretical work that tends to suggest that FDI inflows have a positive effect on economic growth, we do not find a robust causality relationship between FDI and economic growth.
\end{abstract}

JEL Classifications: F43, F14, F23

Key words: FDI, Economic Growth, Transition Countries, EU Countries

\footnotetext{
* Corresponding Author: Anastasia Angelopoulou; Department of Economics, University of Peloponnese, Tripolis Campus, 22100, Greece; Greek; Tel: +30 2710230128, Fax: +30 2710230139, E-mail: aggelopouloua@piraeusbank.gr. Co-Author: Panagiotis Liargovas; Department of Economics, University of Peloponnese, Tripolis Campus, 22100, Greece; Greek; Tel: +30 2710230128, Fax: +30 2710230139, E-mail: liargova@uop.gr.
}

\footnotetext{
Acknowledgements: This research has been co-financed by the European Union (European Social Fund - ESF) and Greek national funds through the Operational Program "Education and Lifelong Learning" of the National Strategic Reference Framework (NSRF) - Research Funding Program: Heracleitus II - Investing in knowledge society through the European Social Fund. We thank two anonymous referees for their comments on an earlier version of this paper. Full responsibility for all shortcomings is ours.
} 


\section{Introduction}

Today's world economy is characterized by increased globalization in which Foreign Direct Investment (FDI) constitutes a business phenomenon of significant importance and frequency. ${ }^{1}$ It is generally believed that FDI contributes to the improvement of the macroeconomic outcomes of the host countries, and in particular, that it enhances their economic growth. In line with this, FDI is considered to be important for the less developed countries, and especially, for the countries in transition. It is argued that FDI may not only provide them with direct capital financing, but it may also create positive externalities via the transfer of technologies and know-how from more technologically advanced countries to the countries in transition. These externalities can take place through the linkages of the entering multinational enterprises with the local suppliers, as well as through increased competition, imitation and training. Through these channels, the incoming FDI could increase the productivity of the countries in transition, enhance their opening up to the global economy, and eventually, it could result to their faster economic integration with more developed countries.

Today's world economy is cheracterized not only by increased FDI, but also by increased economic integration: where more and more countries choose to participate in regional trade unions. ${ }^{2}$ Typically, the member-countries of a trade union share some common features, such as a similar development level. Moreover, member-countries often coordinate, not only their trade policies, but also parts of their economic and fiscal policies. Their coordination, in turn, tends to generate opportunities for internal efficiency, economic stability, and increased FDI inflows within the trade union. In fact, according to empirical evidence, a large percentage of the increase in global FDI during the last decades could be attributed to the extended economic integration. ${ }^{3}$ In other words, regional economic integration seems to provide an important stimulus to FDI within the region concerned.

The objective of this paper is to examine empirically whether or not the above

\footnotetext{
${ }^{1}$ The rise in FDI has been one of the most well documented trends in the world economy over the last three decades. According to the World Investment Report of the United Nations for 2006 (UNCTAD 2006), FDI inward stock has grown on average at 13.5\% per year between 1986 and 2005.

${ }^{2}$ The European Union (EU) constitutes a good example of increased regional economic integration. The number of its membercountries kept on increasing during the years. There were 6 member-countries in 1951 and 28 member-countries in 2013.

${ }^{3}$ Brenton (1996) found that the EU Single Market program lead to a significant increase in investment by EU firms in other EU countries in the late 1980 s.
} 
argued positive relationship between FDI and economic growth exists, as well as whether this relationship differs among country groups that vary in terms of their development levels and their degree of economic integration. In order to do so, we perform a panel data analysis of the impact of FDI inflows and of other main economic factors (e.g. inflation, trade openness) on the GDP growth rate for a period of 20 years in three different country groups: the EU 27 member countries, the European Monetary Union (EMU) 16 member-countries, the 18 Transition Economies. These three country groups differ in terms of the development level of their countries as well as in the degree of economic integration. In particular, the group of the Transition Economies includes countries which are less developed than the countries in the other two groups. At the same time, the EMU group is characterized by a higher degree of economic integration than both the EU-27 group and the Transition Economies group. This is so because the member-countries of the EMU group, in addition to the common economic policies that the EU-27 member-countries also follow, have a common monetary policy. This not the case though for the countries of the Transition Economies group that do not coordinate their economic policies.

We apply a two-Stage Least Square (2SLS) dummy variable estimators model with the use of Instrumental Variables (IV). Our ultimate aim is to use the results of the empirical analysis in order to draw conclusions that could be used in the formation of economic policies that strengthen the potentially positive implications of FDI. As mentioned above, this could be particularly important for the improvement of the economic environment in the countries in transition.

Our work differs from the already existing empirical literature on the FDI-economic growth causality in many aspects. ${ }^{4}$ First, we include a different combination of variables in the exploration of the causality (e.g. amount of trade, gross capital formation, total public spending on education). Second, we consider a large time period, using data for 20 years and, in particular, from 1989 to 2008 which are the years that are of socioeconomic significance for the countries in our data. Third, we simultaneously use three different country samples that allow us to examine the role of a number of distinct policies and features of these country groups. In particular, the simultaneous use (i) allows us to examine whether their different levels of economic development affect our estimates, and (ii) given that the three country groups considered are different in their degree of economic integration and also given that the EMU countries group being the

${ }^{4}$ In Section II, we provide details regarding the related literature. 
most integrated one and the Transition countries group the less integrated one, it allows us to examine the role of economic integration for the FDI-growth relationship.

The rest of the paper is organized as follows. In Section II, we discuss in detail other related empirical literature. Section III describes the data and the methodology that we use, while Section IV contains the specification of our empirical model. We report our results in Section V. Finally, in Section VI, we conclude and discuss a number of possible extensions of our work.

\section{Previous Empirical Literature}

Due to the importance of the FDI and economic growth relationship, it is not surprising that an extensive theoretical and empirical literature on this issue has been developed. Despite the arguments that exist in the theoretical literature in favor of the positive effects of FDI on economic growth, the empirical literature does not always provide support for these effects. For instance, while Borensztein et al. (1998), Blomstrom et al. (1996), Blomstrom and Kokko (2003), Campos and Kinoshita (2002), Moudatsou (2003), Moudatsou and Kyrkilis (2011) find a positive relationship between FDI and growth in the host countries, Bos et al. (1974), Saltz (1992), Alfaro et al. (2000), and Lyroudi et al. (2004) provide evidence for a negative relationship. Moreover, a number of studies (Carkovic and Levine 2005, Blonigen and Wang 2005) conclude that FDI is not related to growth.

The empirical studies of the FDI-growth relationship in the case of Transition countries (Campos and Kinoshita 2002, Lyroudi et al. 2004, Asteriou et al. 2005) also find mixed results. In particular, Campos and Kinoshita (2002) find that FDI has a positive impact on GDP growth in the case of 25 Central and Eastern European and former Soviet Union Transition countries between 1990 and 1998. ${ }^{5}$ They set their core results to a number of sensitivity tests in order to gauge their robustness vis-à-vis potential reverse causality, endogeneity and omitted variable bias.

Lyroudi et al. (2004) employ a Bayesian analysis on panel data, to investigate the FDI-growth relationship for the years 1995 to 1998 . They find that FDI does not have

\footnotetext{
${ }^{5}$ Similar results were found by Madura and Picou (1990), La Follette (1990), and Hooley et al. (1996).
} 
any significant relationship with economic growth in the Transition countries. They derive the same conclusions after splitting their sample into low and high income/ growth countries.

Asteriou et al. (2005) investigate the FDI-growth relationship for a sample of 10 Transition countries for a period of 14 years. They use net inflows of foreign investments and the net portfolio investments, both as a percentage of GDP, as FDI proxies. According to their results, planned foreign investments have a positive and significant effect on the economic growth of these economies. On the other hand, portfolio investments have a negative and insignificant effect. These results could be explained by the fact that stock markets are not fully developed in Transition countries, while their relatively cheaper labor makes them quite attractive to planned FDI.

\section{Data and Methodology}

In our analysis, we use three different samples. The first sample is the EU-27 sample that consists of the 27 member-countries of the EU until 2012. The second sample is the EMU-16 sample that consists of the 16 member-countries of the the European Economic and Monetary Union (EMU). And finally, the third sample is the Transition-18 sample that consists of the 18 countries in transition from centrally planned to market economies. ${ }^{6}$ More details regarding the countries that are included in each sample can be found in Table 1.

\footnotetext{
${ }^{6}$ Following the UNCTADSTAT (2013) classification of countries according to their development status, we include 18 Transition Economies, excluding the Socialist Federative Republic of Yugoslavia, the Union of Soviet Socialist Republics, Serbia, and Montenegro.
} 
Table 1. Data coverage of countries

\begin{tabular}{|l:l|l|l|}
\hline \multicolumn{2}{|c|}{ EU-27 } & \multicolumn{1}{c|}{ EMU-16 } & Transition-18 \\
\hline Austria & Netherlands & Austria & Albania \\
\hline Belgium & Poland & Belgium & Armenia \\
\hline Bulgaria & Portugal & Cyprus & Azerbaijan \\
\hline Cyprus & Romania & Finland & Belarus \\
\hline Czech Republic & Slovakia & France & Bosnia-Herzegovina \\
\hline Denmark & Slovenia & Germany & Croatia \\
\hline Estonia & Spain & Greece & Fyr of Macedonia \\
\hline Finland & Sweden & Ireland & Georgia \\
\hline France & United Kingdom & Italy & Kazakhstan \\
\hline Germany & & Luxembourg & Kyrgyz Republic \\
\hline Greece & & Malta & Moldova \\
\hline Hungary & & Netherlands & Montenegro \\
\hline Ireland & & Portugal & Russian Federation \\
\hline Italy & & Slovakia & Serbia \\
\hline Luxembourg & & Slovenia & Tajikistan \\
\hline Latvia & & Spain & Turkmenistan \\
\hline Lithuania & & & Ukraine \\
\hline Malta & & Uzbekistan \\
\hline & & & \\
\hline & & & \\
\hline
\end{tabular}

The countries in our three samples have the following characteristics. The EU countries are members of the same trade union, and thus, they have no trade barriers among them. Moreover, they follow a number of common policies like trade policy and/or agricultural policy. The (EMU) countries are even more integrated among them, bearing aside the common policies of the EU, they also use the same currency and have a common fiscal policy.

The sample of the Transition countries includes mainly countries which are small and developing that are typically seeking to overcome their small domestic markets, 
low skills, and poor infrastructure. This group of countries also includes post-conflict countries, i.e., war recovery countries that lack confidence to foreign investors, wellstructured commercial justice system and political stability. All of the Transition countries in our sample have introduced reforms towards market economy, but the pace of regulatory change varies. For these countries, crucial characteristics, such as factors of production (relative costs), level of technology, market size and consumer preferences, along with national differences could determine the type of investment for both home and host countries (FDI inflows and outflows). Transition economies typically began their transformation to market economies with well-developed skills, reasonable infrastructure and low sovereign debt. The pace of regulatory change, however, varies from very rapid pro-market reforms to slow or less conventional changes with varying effects on both FDI and growth.

The above three samples are analyzed for a period of 20 years that extends from 1989 up to 2008. The data used are obtained from the World Bank (2012).

In order to examine the FDI-growth causality and how these two variables are related to other growth factors across different countries, we apply the following methodology: multiple regression analysis with panel data. More specifically, we use two different regressions where more than one independent-explanatory variables are used to predict the value of two different dependent ones: $Y 1=$ FDI and $Y 2=\mathrm{GDP}$ Growth. Moreover, we develop a two-Stage Least Square (2SLS) dummy variable estimators model with the use of Instrumental Variables (IV).

The two main sets of theoretical questions that we answer are as follows.

(i) How FDI is related to some of its determinants? In particular, we examine the specific determinants of FDI in three parallel regressions, one for each sample. The dependent variable is FDI and it is explained by seven specific determinants.

(ii) Is FDI growth enhancing? How FDI determines growth compared to other growth factors? More specifically, we examine the effect of FDI on economic growth (GDP growth rate) in three growth regressions. In each of them, we control for a number of standard growth determinants like inflation, initial GDP in addition to FDI, and examine if they are positively or negatively related to growth. Therefore, the dependent variable in our regression is GDP growth and FDI is one of our explanatory variables.

All the variables used are described in Table 2. 
Table 2. Definition of variables

\begin{tabular}{|c|c|c|}
\hline Variable & $\begin{array}{c}\text { Indicator } \\
\text { Name }\end{array}$ & Definition \\
\hline FDI & $\begin{array}{l}\text { Foreign Direct } \\
\text { Investment, } \\
\text { net inflows } \\
\text { (\% of GDP) }\end{array}$ & $\begin{array}{l}\text { Foreign Direct Investment (FDI) are the net inflows of } \\
\text { investment to acquire a lasting management interest } \\
\text { ( } 10 \text { percent or more of voting stock) in an enterprise } \\
\text { operating in an economy other than that of the investor. } \\
\text { It is the sum of equity capital, reinvestment of earnings, } \\
\text { other long-term capital, and short-term capital as } \\
\text { shown in the balance of payments. The series show net } \\
\text { inflows (new investment inflows less disinvestment) in } \\
\text { the reporting economy from foreign investors, and is } \\
\text { divided by GDP. }\end{array}$ \\
\hline $\begin{array}{l}\text { GDP } \\
\text { growth }\end{array}$ & $\begin{array}{l}\text { GDP growth } \\
\text { (annual \%) }\end{array}$ & $\begin{array}{l}\text { Annual percentage growth rate of GDP at market } \\
\text { price based on constant local currency. Aggregates } \\
\text { are based on constant } 2000 \text { US dollars. GDP is the } \\
\text { sum of gross value added by all resident producers in } \\
\text { the economy plus any product taxes and minus any } \\
\text { subsidies not included in the value of the products. It is } \\
\text { calculated without making deductions for depreciation } \\
\text { of fabricated assets or for depletion and degradation of } \\
\text { natural resources. }\end{array}$ \\
\hline $\begin{array}{l}\text { Initial } \\
\text { GDP }\end{array}$ & $\begin{array}{l}\text { GDP } \\
\text { (constant } 2000 \\
\text { US dollars) }\end{array}$ & $\begin{array}{l}\text { GDP at purchaser's prices is the sum of gross value } \\
\text { added by all resident producers in the economy plus } \\
\text { any product taxes and minus any subsidies not included } \\
\text { in the value of the products. It is calculated without } \\
\text { making deductions for depreciation of fabricated assets } \\
\text { or for depletion and degradation of natural resources. } \\
\text { Data are in constant } 2000 \text { US dollars. Dollar figures } \\
\text { for GDP are converted from domestic currencies using } \\
2000 \text { official exchange rates. For a few countries } \\
\text { where the official exchange rate does not reflect the } \\
\text { rate effectively applied to actual foreign exchange } \\
\text { transactions, an alternative conversion factor is used. }\end{array}$ \\
\hline
\end{tabular}




\section{Table 2. Definition of variables}

(Continued)

\begin{tabular}{|c|c|c|}
\hline $\begin{array}{l}\text { Investment } \\
\text { Share }\end{array}$ & $\begin{array}{l}\text { Gross capital } \\
\text { formation } \\
(\% \text { of GDP) }\end{array}$ & $\begin{array}{l}\text { Gross capital formation (formerly gross domestic } \\
\text { investment) consists of outlays on additions to the } \\
\text { fixed assets of the economy plus net changes in } \\
\text { the level of inventories. Fixed assets include land } \\
\text { improvements (fences, ditches, drains, and so on); } \\
\text { plant, machinery, and equipment purchases; and the } \\
\text { construction of roads, railways, and the like, including } \\
\text { schools, offices, hospitals, private residential } \\
\text { dwellings, and commercial and industrial buildings. } \\
\text { Inventories are stocks of goods held by firms to meet } \\
\text { temporary or unexpected fluctuations in production or } \\
\text { sales, and "work in progress". According to the } 1993 \\
\text { System of National Account (SNA), net acquisitions } \\
\text { of valuables are also considered capital formation. }\end{array}$ \\
\hline Openess & $\begin{array}{l}\text { Trade } \\
(\% \text { of GDP) }\end{array}$ & $\begin{array}{l}\text { Trade is the sum of exports and imports of goods } \\
\text { and services measured as a share of gross domestic } \\
\text { product. }\end{array}$ \\
\hline $\begin{array}{l}\text { Government } \\
\text { Spending }\end{array}$ & $\begin{array}{l}\text { General } \\
\text { government } \\
\text { final } \\
\text { consumption } \\
\text { expenditure } \\
(\% \text { of GDP) }\end{array}$ & $\begin{array}{l}\text { General government final consumption expenditure } \\
\text { (formerly general government consumption) includes } \\
\text { all government current expenditures for purchases } \\
\text { of goods and services including compensation } \\
\text { of employees. It also includes most expenditures } \\
\text { on national defense and security, but excludes } \\
\text { government military expenditures that are part of } \\
\text { government capital formation. }\end{array}$ \\
\hline Inflation & $\begin{array}{l}\text { Inflation, } \\
\text { consumer prices } \\
\text { (annual \%) }\end{array}$ & $\begin{array}{l}\text { Inflation, as measured by the consumer price index } \\
\text { reflects the annual percentage change in the cost to } \\
\text { the average consumer of acquiring a basket of goods } \\
\text { and services that may be fixed or changed at specified } \\
\text { intervals, such as yearly. The Laspeyres formula is } \\
\text { generally used. }\end{array}$ \\
\hline
\end{tabular}

${ }^{7}$ In particular, following Kosteletou and Liargovas (2011), we use for this variable the amount of Total Trade divided by GDP, i.e., $(X+M) / \mathrm{GDP}$. 


\section{Table 2. Definition of variables}

(Continued)

\begin{tabular}{|c|c|c|}
\hline $\begin{array}{l}\text { Government } \\
\text { Spending on } \\
\text { Education }\end{array}$ & $\begin{array}{l}\text { Public spending } \\
\text { on education, } \\
\text { total } \\
\text { (\% of GDP) }\end{array}$ & $\begin{array}{l}\text { Public expenditure on education consists of current } \\
\text { and capital public expenditure on education includes } \\
\text { government spending on educational institutions } \\
\text { both public and private, education administration } \\
\text { as well as subsidies for private entities (students/ } \\
\text { households and other privates entities). }\end{array}$ \\
\hline R\&D & $\begin{array}{l}\text { Research and } \\
\text { Development } \\
\text { expenditure } \\
\text { (\% of GDP) }\end{array}$ & $\begin{array}{l}\text { Expenditures for research and development are } \\
\text { current and capital expenditures both public and } \\
\text { private, on creative work undertaken systematically } \\
\text { to increase knowledge, including knowledge of } \\
\text { humanity, culture, and society, and the use of } \\
\text { knowledge for new applications. R\&D covers } \\
\text { basic research, applied research, and experimental } \\
\text { development. }\end{array}$ \\
\hline Tariffs & $\begin{array}{l}\text { Tariff rate, } \\
\text { applied, } \\
\text { weighted mean, } \\
\text { all products ( } \%)\end{array}$ & $\begin{array}{l}\text { Weighted mean applied tariff is the average of } \\
\text { effectively applied rates weighted by the product import } \\
\text { shares corresponding to each partner country. } \\
\text { Data are classified using the Harmonized System } \\
\text { of trade at the six- or eight-digit level. Tariff line } \\
\text { data were matched to Standard International Trade } \\
\text { Classification (SITC) revision } 3 \text { codes to define } \\
\text { commodity groups and import weights. To the extent } \\
\text { possible, specific rates have been converted to their } \\
\text { ad valorem equivalent rates and have been included } \\
\text { in the calculation of weighted mean tariffs. Import } \\
\text { weights were calculated using the United Nations } \\
\text { Statistics Division's Commodity Trade (Comtrade) } \\
\text { database. Effectively applied tariff rates at the } \\
\text { six- and eight-digit product level are averaged } \\
\text { for products in each commodity group. When the } \\
\text { effectively applied rate is unavailable, the most } \\
\text { favored nation rate is used instead. }\end{array}$ \\
\hline
\end{tabular}

(Source) World Data Bank (2010) 
Importantly, we use the data that we have for the three different country groups in order to compare the FDI-growth relationship in each of them. In particular, we first examine the differences in their FDI patterns, taking into account how different determinants formulate the amount of total FDI inflows. Secondly, we examine their differences in growth factors, trying to analyse how FDI inflows affect the total GDP growth of each group of countries. Given that the three country groups under consideration have different economic characteristics and are at different levels of economic integration, their comparison could provide us with some important conclusions regarding the role of economic integration in the global economy.

\section{The Empirical Model}

The economic model used describes the average, systematic relationship between the variables FDI, OPENESS, INV.SHARE, INFLATION, GOV.SPEND., GOV.SPEND. $E D U, \mathrm{R} \& \mathrm{D}$ and Tariffs as following:

$$
\begin{gathered}
F D I=b_{0}+b_{1} \text { OPENESS }+b_{2} I N V . \text { SHARE }+b_{3} I N F L A T I O N+b_{4} G O V . \text { SPEND. } \\
+b_{5} \text { GOV.SPEND. EDU }+b_{6} R \& D+b_{7} \text { TARIFFS }+\varepsilon_{i}
\end{gathered}
$$

where,

$b_{0}=Y(F D I)$ intercept

$b_{1}=$ slope of FDI with OPENESS

$b_{2}=$ slope of FDI with INV. SHARE

$b_{3}=$ slope of $F D I$ with INFLATION

$b_{4}=$ slope of FDI with GOV. SPEND.

$b_{5}=$ slope of $F D I$ with GOV. SPEND. EDU

$b_{6}=$ slope of $F D I$ with $R \& D$

$b_{7}=$ slope of FDI with TARIFFS

$\varepsilon_{i}=$ random error in $F D I$ for observation $i$

The above model describes the expected or average behaviour of $F D I, E(F D I)$, of 
each country in the examined samples. To allow for a difference between observable FDI and the expected value of FDI, we add a random error term, $\varepsilon_{i}=F D I-E(F D I)$. This random error represents all factors, rather than explanatory variables, which cause FDI to differ from its expected value. These factors include geographical, institutional, political and market characteristics of the considered countries.

We use a pooled time-series and cross-section Fixed Effects Model. All behavioural differences between individual countries over time are captured by the intercept of the dummy, $b_{c n}$. Furthermore, we include individual intercepts in order to control each country's specific differences. In particular, we include an intercept dummy variable for the $n$ countries as follows,

$$
D U M_{C 1_{i}}=\left\{\begin{array}{lr}
1 & i=c 1 \\
0 & \text { otherwise }
\end{array}, D U M_{C 2_{i}}=\left\{\begin{array}{lr}
1 & i=c 2 \\
0 \text { otherwise }
\end{array} \ldots D U M_{C n_{i}}=\left\{\begin{array}{lr}
1 & i=c n \\
0 & \text { otherwise }
\end{array}\right.\right.\right.
$$

The restructured regression equation finally used for each sample is as follows,

$$
\begin{gathered}
\text { FDI }=b_{0}+b_{1} \text { OPENESS }+b_{2} \text { INV. SHARE }+b_{3} \text { INFLATION }+b_{4} \text { GOV. SPEND. } \\
+b_{5} \text { GOV. SPEND. EDU }+b_{6} R \& D+b_{7} \text { TARIFFS }+b_{c 1} D U M_{c 1} \\
+b_{c 2} D_{c 2}+b_{c 3} D U M_{c 3}+\cdots+b_{c n} D U M_{c n}+\varepsilon_{i}
\end{gathered}
$$

where,

$D U M_{c i}=$ the Dummy Variable for the $i$ country of the $n$ countries in the sample $b_{c 1}, b_{c 2}, \ldots b_{c n}=$ country's $i$ intercept (country specific constant, country fixed effects).

The Best Linear Unbiased Estimator (BLUE) is the least square estimator (OLS framework), which in this case is a least square dummy variable estimator.

Following the above procedures, we construct the equation for the growth model used to explain the linear relationship between each growth factor (six explanatory variables) and the dependent variable GDP growth. Dummy variables for each country, $D U M_{c n}$, in the three different samples are also included. The equation has the following form,

$$
\begin{gathered}
\text { GDP Growth }=b_{0}+b_{1} F D I+b_{2} \text { Init.GDP }+b_{3} \text { INV.SHARE }+b_{4} \text { OPENESS } \\
+b_{5} \text { GOV. SPEND. }+b_{6} \text { INFLATION }+b_{c 1} D U M_{c 1}+b_{c 2} D U M_{c 2}+ \\
b_{c 3} D U M_{c 3}+\cdots+b_{c n} D U M_{c n}+\varepsilon_{i}
\end{gathered}
$$


where,

$b_{0}=Y(G D P$ growth $)$ intercept

$b_{1}, b_{2}, b_{3}, b_{4}, b_{5}$ and $b_{6}=$ slope of GDP growth with each one explanatory variable $D U M_{c i}=$ the Dummy Variable for the $i$ country of the $n$ countries in the sample $b_{c 1}, b_{c 2}, \ldots b_{c n}=$ counry's $i$ intercept (country specific constant, country fixed effects) $\varepsilon_{i}=$ random error in GDP growth for observation $i$.

A panel data analysis for the above model is used to describe the average, systematic relationship between the variables GDP growth, FDI, Init.GDP, INV.SHARE, OPENESS, GOV.SPEND and INFLATION.

The following three remarks should be made regarding the regression analysis. First, the 20 year-period is grouped in 5 year averages for each variable, in order to capture the effects of economic cycles in long-term growth (for each country in the three samples we have 4 observations to each explanatory variable - comparing to the 20 observations in the regressions of $F D I$ ).

Second, the variable Init.GDP is for each 5 year-period with the average GDP value of the previous year, apart from the year 1989 where the observation of the year 1989 is used (1989 1993: GDP of 1989, 1994 1998: GDP of 1993, 1999 2003: GDP of 1998 and 2004 2008: GDP of 2003).

Third, in econometric models, the problem of endogeneity occurs when an independent variable is correlated with the error term. This implies that the regression coefficient in an OLS regression is biased. In our model, the explanatory FDI has an impact on the dependent variable GDP growth and vice-versa (their covariance is nonzero - $\operatorname{Cov}(G D P$ growth; $F D I) \neq 0$ and thus FDI is an endogenous variable). In this regression, two cases of endogeneity can arise: omitted variables bias and reverse causality. In order to overcome the omitted variables' bias endogeneity, dummy variables were included. To overcome the reverse causality endogeneity, an instrumental variable regression model was developed. Good instrumental variables $z$, should satisfy two conditions:

(i) They should be highly correlated to the endogenous variable, $F D I(\operatorname{Cov}(F D I ; z)$ $\neq 0$ ) in order to improve the efficiency of the instrumental variable estimator and

(ii) They should not be correlated to $G D P$ growth $(\operatorname{Cov}(z ; G D P$ growth $)=0)$, i.e., they should not have a direct effect on $Y$.

The variables $R \& D$ and TARIFFS are found to contribute better to the explanation of FDI. Given this, along with the method of the least square dummy variable 
estimators for the three samples using the equation presented above, the method of the Instrumental Variable (IV) estimators with instruments $z_{1}=R \& D$ and $z_{2}=$ TARIFFS is also used. The latter model is also a two-Stage Least Square (2SLS) estimators model. In order to obtain the instrumental variables estimators, two least square regressions are used:

Stage 1 is the regression of explanatory variable FDI on a constant term, $z_{1}=R \& D$ and $z_{2}=$ TARIFFS, in order to obtain the predicted values of FDI $\hat{x}$ (reduced form model estimation).

Stage 2 is the ordinary least square estimation of a multiple linear regression with dependent variable GDP growth and explanatory variable FDI.

\section{Empirical Results}

\section{A. FDI regression}

The results of the FDI model are summarized in Table 3. 
Table 3. FDI Regression

Dependent Variable: FDI

\begin{tabular}{|l|c|c|c|}
\hline & \multicolumn{3}{|c|}{ Regression Coefficients } \\
\hline & EU & EMU & TRANSITION \\
\hline Openess & $0.211^{* * *}$ & $0.240^{* * *}$ & -0.095 \\
\hline Investment Share & $(4.52)$ & $(2.81)$ & $(-1.34)$ \\
\hline & 0.129 & -0.212 & $0.662^{* *}$ \\
\hline Inflation & $(0.77)$ & $(-0.63)$ & $(2.60)$ \\
\hline & -0.026 & 0.296 & $-0.509 * *$ \\
\hline Government Spending & $(-0.30)$ & $(1.16)$ & $(-2.09)$ \\
\hline & -0.701 & -1.567 & -0.794 \\
\hline Government Spending on Education & 0.028 & -0.078 & $(-0.80)$ \\
\hline & $(0.02)$ & $(-0.03)$ & $(1.50)$ \\
\hline Tariffs & $1.727 * *$ & 1.860 & 0.918 \\
\hline & $(2.40)$ & $(1.53)$ & $(1.95)$ \\
\hline R\&D & 1.882 & $1.243 * *$ & $48.208^{*}$ \\
\hline & $(0.53)$ & $(2.13)$ & $(0.97)$ \\
\hline Number of observation & 0.412 & 0.460 & 0.865 \\
\hline & 199 & 111 & 23 \\
\hline
\end{tabular}

(Notes) ( i ) Numbers in parenthesis under the estimated coefficients denote $t$ statistics $\left(t_{\text {stat }}\right)$.

(ii) All regressions include a $D U M M Y$ variable for each country.

(iii) *** denote statistical significance at the $1 \%$ level,

** denote statistical significance at the $5 \%$ level,

* denote statistical significance at the $10 \%$ level.

As it follows from Table 3, in the EU-27 member-countries, as well as in the EMU16 member-countries, there seems to be a statistically significant positive relationship between FDI and Openness, Tariffs, and R\&D. In particular, for each 1\% increase in Openness, FDI inflows increase by around 21\% 24\%. Moreover, for all the EU member-countries, a 1\% increase in Tariffs seems to increase the FDI inflows by more 
than $172 \%$. This result is in line with the theoretical argument according to which FDI from overseas (China, Japan or the US) will increase if higher tariffs are imposed (tariff-jumping behavior). At the same time, if R\&D increases by $1 \%$, FDI inflows increase by more than $124 \%$ in the EMU countries. This last result seems to justify the increased emphasis that the EU places during the last few years on its research policy (EU Research and Innovation Policy). More specifically, within this policy the EU designs and funds a number of research programs that aim at supporting investments in various research areas that could result into innovations and technological advances that could, in turn, increase its competitiveness in the world economy.

For the 18 Transition countries, the results seem to be different. Interestingly, Openness does not exert any significant influence on their FDI inflows. Moreover, Inflation and Investment Share are statistically significant in their case, while they were not in the case of the EU and the EMU member-countries. In particular, if domestic investment increases by $1 \%$ in the Transition countries, the FDI inflows increase by $66 \%$, while they decrease by $51 \%$ if the inflation's rate increases by $1 \%$. Finally, we see that, although in the $1 \%$ level of significance, R\&D affect FDI inflows positively in the Transition countries. In particular, an increase in R\&D by $1 \%$ in the Transition countries brings about a significant increase in FDI inflows, increasing them by $4.820 \%$.

These results suggest that if the Transition countries increase their domestic investments, they could attract more FDI. Furthermore, they suggest that if the Transition countries improve their economic stability, e.g., by participating in a trade union, they could also increase their attractiveness as FDI host countries. Finally, for the Transition countries, more expenditure on $R \& D$ could work as a significant FDI enhancing factor.

\section{B. Growth regression}

The results of the growth estimations computed are summarized in Table 4 . 
Table 4. Growth Regression

Dependent Variable: GDP growth

\begin{tabular}{|l|c|c|c|}
\hline & \multicolumn{3}{|c|}{ Regression Coefficients } \\
\hline & EU & EMU & TRANSITION \\
\hline Foreign Direct Investment & 0.008 & 0.002 & -0.086 \\
\hline Initial GDP & $(0.40)$ & $(0.23)$ & $(-1.47)$ \\
\hline & $-0.041^{* * *}$ & $-0.353^{* * *}$ & $-12.102 * * *$ \\
\hline Investment Share & $(-3.56)$ & $(-4.90)$ & $(-4.54)$ \\
\hline & -0.024 & $0.124 * *$ & 0.588 \\
\hline Openess & $(-0.34)$ & $(2.26)$ & $(0.42)$ \\
\hline & $0.088^{* * *}$ & $0.058^{* * *}$ & 0.025 \\
\hline Government Spending & $(4.80)$ & $(3.78)$ & $(0.49)$ \\
\hline & $0.278^{*}$ & -0.184 & $-1.810^{* * *}$ \\
\hline Inflation & $(1.76)$ & $(-1.16)$ & $(-5.25)$ \\
\hline & $-0.452^{* * *}$ & $-0.186 * * *$ & - \\
\hline $\mathrm{R}^{2}$ & $(-6.77)$ & $(-2.73)$ & - \\
\hline Number of observation & 0.714 & 0.807 & 0.597 \\
\hline
\end{tabular}

(Notes) ( i ) Numbers in parenthesis under the estimated coefficients denote $t$ statistics $\left(t_{\text {sta }}\right)$.

(ii) All regressions include a $D U M M Y$ variable for each country.

(iii) *** denote statistical significance at the $1 \%$ level,

** denote statistical significance at the $5 \%$ level,

* denote statistical significance at the $10 \%$ level.

For none of the three samples, FDI exerts a robust positive influence on economic growth. Thus, based on these results, we cannot claim that there is a positive effect of FDI on economic growth. However, according to Table 4, GDP growth is positively related to Openness, in all cases and statistically significant in the case of the EU and the EMU member-countries samples. This means that when more goods are imported and exported, firms' productivity increases, and thus, welfare is augmented. Regarding the initial GDP, we observe that, in all the country groups, it is negatively and statistically 
significant related to the GDP growth. In other words, if countries are relatively rich (high income-high initial GDP), their growth rates are expected to be low. Additionally, Table 4 reveals that the relation between Inflation and GDP growth rate is also negative, at least in the EU and in the EMU member-countries. What is interesting is that in the EMU sample (where the inflation Maastricht Treaty criterion is established), the negative effect of inflation on economic growth is weaker than in the EU sample: a $1 \%$ increase in inflation results into a decrease by $18 \%$ in the GDP growth in the EMU member-countries and by $45 \%$ in the EU member-countries. Finally, we note that the investments in education have a negative effect on the GDP growth of the Transition economies: a 1\% increase in Government Spending decreases GDP growth by $181 \%$. This suggests that during the 1989 2008 period, the productivity boost in the Transition countries was probably based on low skilled and low cost labor.

\section{Growth regression}

The results of the instrumental growth estimations are presented in Table 5. 
Table 5. Growth Regression (Instrumented)

Dependent Variable: GDP growth

\begin{tabular}{|l|c|c|c|}
\hline & \multicolumn{3}{|c|}{ Regression Coefficients } \\
\hline & EU & EMU & TRANSITION \\
\hline Foreign Direct Investment & 0.029 & -0.017 & 1.547 \\
\hline & $(1.23)$ & $(-0.92)$ & $(1.12)$ \\
\hline Initial GDP & $-0.275^{* *}$ & $-0.365^{* * *}$ & 2.667 \\
\hline & $(-2.87)$ & $(-4.80)$ & $(0.29)$ \\
\hline Investment Share & $0.108^{*}$ & $0.127^{* *}$ & -0.742 \\
\hline & $(1.69)$ & $(2.20)$ & $(-1.14)$ \\
\hline Openess & $0.037^{* *}$ & $0.055^{* *}$ & 0.184 \\
\hline & $(2.47)$ & $(3.35)$ & $(1.69)$ \\
\hline Government Spending & -0.102 & -0.208 & -1.041 \\
\hline & $(-0.78)$ & $(-1.24)$ & $(-1.17)$ \\
\hline Inflation & $-0.019^{* *}$ & $-0.203^{* *}$ & - \\
\hline & $(-2.98)$ & $(-2.79)$ & - \\
\hline $\mathrm{R}^{2}$ & 0.780 & 0.787 & 0.483 \\
\hline Number of observation & 79 & 60 & 38 \\
\hline
\end{tabular}

(Notes) ( i ) Numbers in parenthesis under the estimated coefficients denote $t$ statistics $\left(t_{\text {stal }}\right)$.

(ii) All regressions include a $D U M M Y$ variable for each country.

(iii) $* * *$ denote statistical significance at the $1 \%$ level,

** denote statistical significance at the $5 \%$ level,

* denote statistical significance at the $10 \%$ level.

As expected, in the EU and EMU member-countries, the GDP growth rates are positively and statistically significant related to Openness and Investment Share and negatively and statistically significant related to the Initial GDP and to Inflation. These results are not robust in the case of the Transition countries.

Regarding the FDI-economic growth relationship, our main result is identical to the one we have obtained from the growth regressions without the instruments. That is, the relationship between FDI and growth is again not robust. The only differences that we 
identify when we compare our results with and without instruments are the following. When we use the instruments, we obtain a greater positive impact of FDI on GDP growth for the EU member-countries than before where in this case, a 1\% increase in FDI affects the GDP growth positively by almost 3\%. For the EMU countries, we find now that an increase in FDI no longer has a positive impact on GDP growth. In particular, we find that a $1 \%$ increase in FDI affects the GDP growth of the EMU member-countries negatively by less than $2 \%$. We also find the opposite result for the Transition countries where a 1\% increase in FDI increases their GDP growth by almost $155 \%$.

Summing up, checking the robustness of our results, we find again that for all the country groups, the relationship between FDI and growth is not significant. Thus, we conclude that there is no robust relationship between FDI and economic growth in the three country groups under consideration. We should note that these findings are similar to the respective results of Carkovic and Levine (2005) and Blonigen and Wang (2005) for developed and developing countries but we obtain them with the use of different data and different methodology.

Our results regarding the non significant impact of FDI on the GDP in the case of Transition economies are also in accordance with the ones found in Lyroudi et al., who focus on Transition countries. Still, our paper differs significantly from the paper of Lyroudi et al. (2004). In particular, while Lyroudi et al. (2004) use a Bayesian analysis on panel data, our panel data analysis of FDI-economic growth relation is formed on a 2SLS instrumented variable model (use of 6 explanatory variables and 2 instrumented ones). Also, while Lyroudi et al. (2004) base their analysis on the data for only four years (1995 1998), we consider a richer data set for a period of 20 years. Importantly, in contrast to Lyroudi et al. (2004), we do not restrict our attention to the case of the Transition economies. We explore the FDI-economic growth relationship in three different groups of countries, which are characterized by different degree of economic integration, and compare the outcomes that we obtain in each group.

When Asteriou et al. (2005) employ an estimation method, the fixed effects method, which is similar to ours, they also find the same result as ours that FDI is not significant for economic growth in the Transition countries. When, instead, they use alternative methods, such as the common constant method of estimation and the random effects method, they conclude that the influence of FDI on growth is both positive and significant as long as FDI is defined as net inflows of foreign investments. What differentiates our work from Asteriou et al. (2005) is that while in their analysis, 
besides exploring the role of FDI, they also explore the role of the labor force, GDP per capita and inflation for economic growth, we explore the role of other economic factors such as trade-openness, government spending, initial GDP and gross capital formation, which are very significant for the Transition economies. Moreover, we use data for a longer time period and a larger sample of Transition countries. Importantly, as mentioned above, by not restricting our attention to Transition countries, we obtain richer results than Asteriou et al. (2005) that allow us to identify differences among country groups with different characteristics.

Our findings are not in accordance with the ones of Campos and Kinoshita (2002), who find that in Transition economies, FDI is statistically significant for economic growth. They also find that the effect of FDI on economic growth does not necessarily depend on the host country's absorptive capacity since the level of human capital in Transition economies is already above the minimum threshold. The difference in our results is firstly due to the fact that they use different variables in their regression model. We both analyze the average, systematic relationship between growth rate and FDI, gross domestic fixed investment, government consumption and expenditures and initial GDP. But instead of the other variables that we use: trade-openness, inflation, government spending on education, R\&D and tariffs, they in addition to the previous common variables use only the basic education gross enrolment ratio and the population growth. Second, the difference in our results is also due to the fact that they use an interaction term between FDI and human capital (measured as enrolment rates in secondary school) in order to capture the technology transfer under FDI. The use of this term provides the statistically significant results. Finally, we should note that they use data for a shorter period of time (1990 1998) in comparison to our data period (1989 2008) and they restrict their attention only to Transition countries.

\section{Concluding Remarks}

We have examined the causal relationship between FDI and economic growth. We have done so by performing a panel data analysis for a period of 20 years (1989 2008) in three different samples: EU-27 member-countries, EMU-16 member-countries, and 18 Transition countries. The exploration of how the differences among these three 
country groups affect the specific factors that determine the FDI inflows and the FDI and economic growth relationship has been primary in our analysis.

Our results indicate how different levels of economic integration affect the determinants that attract FDI. In particular, in the case of economically integrated countries (EU and EMU countries), we conclude that the level of openness is very important for attracting FDI. Moreover, the most integrated countries (EMU) are more likely to attract FDI when R\&D expenditure increases while the less integrated countries (EU) attract more FDI when tariffs increase. In the non-integrated countries (Transition economies), FDI is attracted by an increase in domestic investment and in R\&D investments as well as by a decrease in inflation.

Regarding the FDI-growth relationship, our results indicate that there is no robust causality relationship between them. Although FDI exerts a slightly positive effect on GDP in the case of the EU and EMU member-countries and a slightly negative effect on GDP in the case of the Transition countries, all these effects are statistical insignificant. In other words, despite the straightforwardness of the theoretical arguments that claim FDI enhances economic growth, empirically we do not establish such a relationship.

In order to shed more light on the relationship between FDI and economic growth and to examine the robustness of our results, we have attempted to overcome endogeneity with the use of $\mathrm{R} \& \mathrm{D}$ and tariffs as instrumental variables. By applying this method, we have found again that there is no robust causal relationship between FDI and growth. The main differences from our initial approach are that with the use of the instruments, we find that there is a greater positive influence of FDI on GDP in the case of the EU member-countries, a positive effect of FDI on the GDP of the Transition countries, and a negative effect on the GDP of the EMU member-countries. These results, although they are not statistically significant, seem to suggest that the higher the degree of economic integration, the less FDI can contribute to a country's economic growth.

Therefore, by accounting for special countries' effects, economic cycles' effects, omitted variable bias endogeinety, and reverse causality endogeneity, we have reconciled most of our initial empirical findings: there is no reliable panel data and empirical evidence supporting the claim that FDI per se accelerates growth, especially in the EU and EMU member-countries.

Our above mentioned results are in accordance with the ones of Carkovic and Levine (2005), and Blonigen and Wang (2005) concerning developing and developed countries. Regarding the comparison of our results with the results of the literature 
on the FDI-growth relationship in the case of Transition countries, we conclude that our main findings differ from Campos and Kinoshita (2002) who find a positive relationship. However, they are in accordance with the results of Lyroudi et al. (2004) and Asteriou et al. (2005). We stress though that both the samples and the methodology that we have used differ significantly from the respective ones in Lyroudi et al. (2004) and Asteriou et al. (2005). Furthermore, Campos and Kinoshita (2002), Lyroudi et al. (2004), and Asteriou et al. (2005), in contrast to us, they have not tested and accounted for the role of the differences, in terms of development and integration levels, among different country groups for the FDI-growth relationship.

Although we have not identified a statistical significant relation between FDI and growth, still, our results could be useful in the design of policy, especially in the Transition countries that seek to achieve high GDP growth rates. In particular, policy makers should be aware that there is a positive causal relationship between FDI inflows and GDP growth, which is evidenced empirically (but is not statistically significant) in the case of Transition economies. This finding suggests that measures that attract FDI from more developed countries such as FDI subsidies, should be taken, in order to improve the economic development of Transition countries and to speed up their economic integration with more developed European countries.

Our research effort can be extended in a number of ways. First, one could use alternative econometric specifications in order to further examine the robustness of the FDI-economic growth relationship. Second, one could use different conditioning information sets and samples and alternative databases for FDI. Finally, one could apply sub-period analysis, i.e., divide the time period to an early period up to late 1990 s, to a pre-accession period (1998 2003) and to a mature period (post 2004).

Received 9 April 2013, Revised 15 December 2013, Accepted 17 February 2014 


\section{References}

Alfaro L., A. Chanda, S. Kalemli-Ozcan, and S. Sayek. (2004), "FDI and Economic Growth: The Role of Local Financial Markets", Journal of International Economics, 64 (1), 89-112

Asteriou D., X. Dassiou, and D. Glycopantis. (2005), "FDI and Growth: Evidence from a panel of European Transition countries”, Spoudai, 55 (1), 9-30

Balasubramanyam V. N., M. Salisu, and D. Sapford. (1999), "Foreign Direct Investment as an Engine of Growth", Journal of International Trade and Economic Development, 8 (1), $27-40$

Barrios S., S. Dimelis, H. Louri, and E. Strobl. (2004), "Efficiency Spillovers from Foreign Direct Investment in the EU Periphery: A Comparative Study of Greece, Ireland and Spain", Review of World Economics, 140 (4), 688-705

Blomstrom M., and A. Kokko. (2003) "The Economics of International Investment Incentives", National Bureau of Economic Research, NBER 9489.

Blomstrom M., R. E. Lipsey, and M. Zejan. (1996), "Is Fixed Investment the Key to Economic Growth", The Quarterly Journal of Economics, 111 (1), 269-276

Blonigen B. A. and M. Wang. (2005), "Inappropriate Pooling of Wealthy and Poor Countries in Empirical FDI Studies", National Bureau of Economic Research, NBER Working Papers 10378,

Brenton P., F. DiMauro, and M. Lücke. (1998), “Economic integration and FDI : an empirical analysis of foreign investment in the EU and in Central and Eastern Europe", Kiel Working Papers 980

Brenton P. (1996) "The Impact of the Single Market on Foreign Direct Investment in the EU", Report for DGII

Borensztein E., J. De Gregorio, and J.-W. Lee. (1998), "How Does Foreign Direct Investment Affect Economic Growth?", Journal of International Economics, 45 (1), $115-135$

Bos, H. C., M. Sanders, and C. Secchi. (1974), "Private Foreign Investment in Developing Countries: A Quantative Study on the Microeconomic Effects", Dardecht: 
Reidel

Campos F. N. and Y. Kinoshita. (2002), "Foreign Direct Investment as Technology Transferred: some panel data evidence from the transition economies", The Manchester School, 70 (3), 659-763

Carkovic M. and R. Levine. (2005), "Does Foreign Direct Investment Accelerate Economic Growth?, in Does Foreign Direct Investment Promote Development?", ed. T. H. Moran, E. M. Graham and M. Blomstrom, Washington, DC: Institute for International Economics, 195-220

Carcovic M. and Levine R. (2002), “Does Foreign Direct Investment Accelerate Economic Growth?", Department of Business Finance, University of Minessota, Working paper Series.

De Mello L.R. (1997), "Foreign Direct Investment in Developing Countries: a Selective Survey", Journal of Development Studies, 34 (1), 1-34

Gao T. (2005), "Foreign Direct Investment and Growth under Economic Integration", Journal of International Economics, 67, 157-174

Hooley G., Cox T., Shipley D., Fahy J., Beracs J., Kolos K. (1996), "Foreign Direct Investment in Hungary: Resource Acquisition and Domestic Competitive Advantage", Journal of International Business Studies, 4, 683-709

Kosteletou N., and Liargovas P. (2011), "FDI inflows and trade openness in Southeastern Europe in Recent Economic Crisis and Future Development Tendencies", Proceedings of the 7th International Conference of Association of Economic Universities of South and Eastern Europe and the Black Sea Region (ASECU) and Black Sea Countries (SEE \& BSC), Rostov-on-Don, Russia

La Follette C. (1990), "Eastern Europe: No Place for the Politically Naïve", Mergers and Acquisitions, 25, 24-29

Lyroudi K., J. Papanastasiou, and A. Vamvakidis. (2004), "Foreign Direct Investment and Economic Growth in Transition Economies", South Eastern Europe Journal of Economics, 2 (1), 97-110

Markusen J.R, and A.J. Venables. (1999), "Foreign Direct Investment as a Catalyst for Industrial Development", European Economic Review, 43 (2), 335-356 
Madura J. and Picou, A. (1990), "US and German Market Reactions to Foreign Investment in Eastern Bloc Countries", Journal of International Securities Markets, 349-357

Moudatsou A. (2003), "Foreign Direct Investment and Economic Growth in the European Union", Journal of Economic Integration, 18 (4), 689-707

Moudatsou A., and Kyrkilis D. (2011), "FDI and Economic Growth: Causality for the EU and ASEAN", Journal of Economic Integration, 26 (3), 554-577

Saltz S. (1992), “The Negative Correlation Between Foreign Direct Investment and Economic Growth in the Third World: Theory and Evidence", Rivista Internazionale di Scienze Economiche e Commerciali, 39 (7), 617-633

UNCTAD (2006), “World Investment Report 2006”, United Nations, New York and Geneva

UNCTAD (2007), “World Investment Report 2007”, United Nations, New York and Geneva

UNCTADSTAT (2013), "Classification of Geographical Regions”, United Nations, New York and Geneva

Zhang K.H. (1999), "FDI and Economic Growth: Evidence From Ten East Asian Econmies", Economia Internationale, 11 (4), 517-53 